WellBeing International

WBI Studies Repository

$1-2003$

\title{
Toxicology and New Social Ethics for Animals
}

Bernard E. Rollin

Colorado State University

Follow this and additional works at: https://www.wellbeingintlstudiesrepository.org/acwp_arte

Part of the Animal Experimentation and Research Commons, Animal Studies Commons, and the Bioethics and Medical Ethics Commons

\section{Recommended Citation}

Rollin, B. E. (2003). Toxicology and new social ethics for animals. Toxicologic pathology, 31(1 suppl), 128-131.

This material is brought to you for free and open access by WellBeing International. It has been accepted for inclusion by an authorized administrator of the WBI Studies Repository. For more information, please contact wbisr-info@wellbeingintl.org.

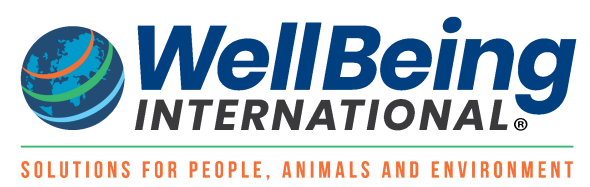




\title{
Toxicology and New Social Ethics for Animals
}

\author{
Bernard E. Rollin \\ Colorado State University
}

\section{KEYWORDS}

animal welfare, animal rights, new social ethic for animals, toxicology

\begin{abstract}
The issue of animal treatment has emerged as a major social concern over the past three decades. This ramified in a new ethic for animal treatment that goes beyond concern about cruelty and attempts to eliminate animal pain and suffering, whatever its source. This is evidenced by laws governing animal research in many countries. Insofar as toxicology can entail significant and prolonged animal suffering, it is at loggerheads with this new ethic. Ways are suggested for the toxicological community to put itself in harmony with the ethic and thereby preserve its autonomy.
\end{abstract}

There can be no question in the mind of any person who tracks social change in the western world that concern for animal treatment has become a burgeoning international issue during roughly the past 3 decades, and particularly since the early 1980s. For example, according to the National Cattlemen's Association, Congress has consistently during this period received more letters, telephone calls, and other contacts on issues of animal welfare than on any other issue. Sweden and the European Union have, in essence, abolished confinement agriculture as we understand it in North America. And, at the same time, many countries have seen the promulgation of meaningful legislation aimed at assuring the welfare of animals in research, often, as occurred in the United States, against significant protestations from the research community that such regulation will hinder research advances in human health. In order to properly assess the relevance and expectations of social animal welfare concerns to toxicology, it is necessary to briefly summarize the sources and nature of such burgeoning social preoccupation with animal treatment (1).

The emergence of a systematic social ethic whose purview extends to the treatment of laboratory animals is a relatively recent phenomenon, as evidenced by the fact that researchers in the United States basically enjoyed carte blanche in the use of animals until the mid 1980s. For most of the 19th and 20th centuries, the only consensus ethical principle extant in society for the treatment of animals was a prohibition against overt, willful, intentional, needless, wanton cruelty, as expressed in anticruelty legislation. Concerned as much with ferreting out sadistic individuals who might begin with animals and move to humans as with protecting animals, these laws therefore did not address "normal," "necessary," "beneficial," sources of animal suffering, such as agriculture, research, hunting, trapping, or education; these are typically exempted from the anticruelty laws by statute or else have been excluded by judicial decision. Rather, the cruelty laws focused on deviant behavior leading to "unnecessary" animal suffering. 
It is only in the past decade that society has begun to realize that a mere fraction of animal suffering is in fact a result of overt cruelty-the vast majority of animal suffering at human hands in fact grows out of such decent motivations as increasing knowledge, curing disease, increasing efficiency of food production, protecting humans against toxic substances, and so on.

A simple thought experiment that I employ with a wide variety of audiences, ranging from biomedical researchers and ranchers to animal rights advocates, will make this clear. I ask my audiences to consider a pie chart representing the total amount of suffering that animals experience at human hands. What percentage of that suffering, I continue, is the result of deliberate, sadistic, intentional cruelty? All of my audiences give the same reply-well under $1 \%$. Society has thus come to realize and to be concerned with the fact that the traditional social ethic for animals and the laws reflecting it are conceptually inadequate for dealing with the vast majority of animal suffering.

Why has this demand for a new ethic occurred only recently, when the limited ethic of anticruelty was considered adequate for most of the history of civilization? There are a variety of factors explaining this social change, including the urbanization of society and the correlative emergence of the companion animal-rather than agricultural animal—as the paradigmatic exemplar of an animal in the public mind; the media discovery that, as one reporter told me, "animals sell papers"; the natural fit between the concerns about disenfranchised humans inadequately protected by our social ethic-women, blacks, the handicapped, children, etc-and its extension to animals; and the emergence of highly articulate spokespersons for animal interests. But the major factor explaining the emergence of recent significant moral concern about animal treatment has been the gradual realization by society that the nature of animal use in society changed precipitously after World War II.

The key to the emergence of the new ethic is this: The major use of animals in society was and is, agricultural. Before the mid-20th century, the essence of animal agriculture was husbandry. (The origin of the word is revealing; "husbandry" is Old Norse, and literally is "hus/bond" D "bonded to the house.") People who used animals put those animals into environments for which they were evolved and adapted, and then augmented their natural ability to cope with additional food, shelter, protection from predators, etc. The Biblical shepherd who leads the animals to green pastures is the lovely paradigm case of this approach. (The fact that the $23^{\text {rd }}$ Psalm uses husbandry as a metaphor for God's relationship to humans itself bespeaks the power of its hold on our thinking.) Producers did well if and only if their animals did well. Productivity and welfare were inextricably intertwined. This is what has aptly been called "the ancient contract"- "we take care of the animals and they take care of us," as ranchers in the western United States say. No rational producer could, for example, have attempted to raise 100,000 egg-laying chickens in one building — he would have had all his animals succumb to disease in weeks.

In contrast, when "animal husbandry" departments symbolically became "animal science" departments in the 1940s and 1950s, industry replaced husbandry, and the values of efficiency and productivity above all else entered agricultural thinking and practice. Whereas traditional agriculture was about putting square pegs in square holes, round pegs in round holes, and creating as little friction as possible while doing so, "technological sanders" such as antibiotics, vaccines, hormones, and bacterins allowed us to produce animals in environments that did not suit their natures but were convenient for us. For example, one could now raise 100,000 chickens in 1 building, with the animals suffering in ways that did not impact on productivity.

Similarly, and more directly relevant to our discussion, the rise of significant amounts of biomedical research and toxicity testing on animals directly after World War II also differed markedly from husbandrybased animal use in traditional agriculture. After all, in research we inflict disease on animals, wound, burn, fracture, and poison them for our benefit, or to the benefit of other animals, with no compensatory 
benefit to the animal subjects. In essence, when society slowly began to realize that unlike traditional animal use, contemporary animal use no longer assured the well-being of the animals used, it began to demand legislated assurances of animal welfare to fill the lacuna left by the absence of the natural assurances implicit in the unspoken contract of husbandry agriculture. In Britain, concern was first directed at animal agriculture in the 1960s, with concern about research emerging later; in the United States, that order was reversed. A recent article from Europe boldly affirms that "in nearly every parliament of the Member States of the Council of Europe," there is growing concern for the welfare of laboratory animals (2).

Whereas the anticruelty ethic focused only on outrageous, useless, sadistic, counterproductive infliction of pain and suffering on animals, the emerging ethic focuses on the pain associated with "legitimate," mainstream animal use. It is correlatively indubitable that the core of all recent legislation and regulation pertaining to animal research in Western Europe, North America, Australia, and New Zealand is the control and minimization of pain and suffering, as well as an ever-increasing tendency to press forward alternatives to painful animal procedures and uses. Thus, for example, a January 1998 article in Lab Animal indicated that "increasing concern within and without the scientific community over pain and distress in animals has made the production of monoclonal antibodies [MAbs] highly controversial ... [with] some European countries having gone as far as banning vivo production of MAbs using the ascites method" (3). In the United States, pain engendered in laboratory animals must be controlled by anesthesia, analgesia, sedation, and early euthanasia endpoints, for example for tumor growth and disease processes, aimed at minimizing suffering. In Britain, an animal suffering uncontrollable pain and distress must be euthanized as soon as the situation is understood (4). For reasons of controlling pain and suffering, US journals are increasingly unlikely to publish papers using death as an endpoint, even though the late endpoint may well provide valuable information. In other words, globally, there is a consensus emerging that not every human benefit is worth any amount of animal suffering (vide public rejection of cosmetics companies utilizing safety testing on animals, and the spectacular growth of those companies disavowing such testing.)

I was closely associated with the creation of the US laboratory animal laws. These laws were drafted at CSU in the late 1970s by me and 2 laboratory animal veterinarians in the face of our realizing that 1 ) society was growing ever-increasingly concerned about animal treatment, and 2) animals were not getting the best possible treatment consonant with their use in research. For example, when I searched the literature in 1979, I could find no analgesic regimens for laboratory animals discussed anywhere. This was in part due to an ideology rife and unquestioned in the scientific community, which was taught as gospel to nascent scientists in conjunction with the basic facts of their discipline (5). This ideology affirmed that science was "value-free" in general and "ethics-free" in particular and was born out of a desire to expunge the unverifiable from science, as Einstein did with absolute space and time. Because, as Wittgenstein once remarked, one can take an inventory of all the facts in the universe and not find it a fact that "killing is wrong," ethics is not relevant to science. So widespread was this ideology that the head of the $\mathrm{NIH}$, in 1989, remarked that while scientific advances such as genetic engineering were always controversial, "science should never be hindered by ethical considerations."

The second component of scientific ideology arose from much the same sources. This was the denial of the relevance of subjective mental states such as pain, thoughts, and feelings to science. Psychology became behaviorism, and the first US textbook of veterinary anesthesia does not even list felt pain as a reason for anesthesia.

Our law was designed to force the "reappropriation of common sense" by the scientific community with regard to ethics and pain and distress via ACUC protocol review. This has worked splendidly in my view, though at the time I was called a "Nazi" and an "apologist for the lab trashers" by the New England 
Journal of Medicine, and in the same week, a "sellout" for "accepting the reality of science," by the animal rights journal Agenda. (Three years later we were called "the salvation of biomedicine" by the head of the Institute for Laboratory Animal Resources [ILAR] of the National Academy of Science.)

Much of the research community at the time opposed the laws and even made a movie entitled "Will I be All Right, Doctor?" essentially arguing that our laws would prevent medicine from curing sick children. Despite this threat, and despite the fact that $90 \%$ of research animals are noncuddly rats and mice, the public forced through Congress 2 laws in 1985.

TABLE 1.-How strongly do you approve or disapprove of the use of animals like mammals and birds in research and testing when the animals experience severe, moderate, or little or no pain or distress?

\begin{tabular}{|lccc|}
\hline & \multicolumn{3}{c|}{ Percentage approving or disapproving } \\
\cline { 2 - 4 } & Little or No & Moderate & Severe \\
\hline Strongly approve & 30 & 11 & 8 \\
Somewhat approve & 32 & 23 & 13 \\
Total approve & 62 & 34 & 21 \\
Strongly disapprove & 20 & 37 & 57 \\
Somewhat disapprove & 13 & 23 & 18 \\
Total disapprove & 33 & 60 & 75 \\
\hline Survey conducted for The HSUS by an independent polling firm, which interviewed 757 Americans nationally on \\
September 23, 2001. (Quoted by permission of Humane Society of the United States). \\
\hline
\end{tabular}

It is clear that the major public concern about animal use is directed not against painless killing of animals but against suffering. Revealing evidence for this claim comes from a 2001 survey chartered by the Humane Society of the United States, summarized in Table 1. Clearly, public support of research declines as pain and suffering is prolonged.

Indeed, a large survey by George Gaskell of the London School of Economics shows that, contrary to regulators' beliefs in Europe, European citizens reject various biotechnology modalities not out of fear, but out of a belief that certain modalities are morally wrong (6). When queried about biotechnological production of medicine, genetic testing for disease, crop biotechnology, food biotechnology (eg, increasing shelf life), xenotransplanataion, and creating animal models of disease using biotechnology, the majority of 17,000 people surveyed were willing to accept the first 4 modalities because they were useful (despite beliefs that they were more dangerous than the last 2) but rejected the last 2 as morally unacceptable. Although Gaskell did not seek reasons for the rejection, I believe that I have shown elsewhere that at least creation of animals models of human disease were rejected on the grounds that the animals would experience uncontrollable suffering (7). The foregoing ruminations are given sudden and immediate support by a recent story in Nature (March 28, 2002). According to the story, "Germany is poised to pass a constitutional amendment that may lead to tighter restrictions on the use of animals in research." Supported by all major political parties, the amendment affirms that "animals must be treated as fellow creatures and protected from avoidable pain." The president of an animal protection group predicted that "The constitutional freedom to research will no longer be enough to legally justify the use of animals in research," and the research community has recognized this law as inevitable. The amendment did indeed pass in May of 2002. 
This is unquestionably the wave of the future internationally. And in the face of this sort of development, researchers should recall the nature of the relationship between social ethics and professional ethics.

Every society, to assure social order, must articulate a social consensus ethic governing matters deemed essential. This is usually "written large" in Plato's phrase, in the legal system. Thus we morally and legally disallow rape, bank robbery, murder, fraud, etc. Matters with moral import not affecting the social order are left, generally, to one's personal ethic-eg, in today's society what one believes religiously, to whom and whether one gives charity, what one reads, and so on. Things move in and out of the social ethic as society changes - thus control of nonviolent sexual behavior was surrendered to the personal ethic from the social beginning in the 1960s' "sexual revolution," yet at roughly the same time hiring and firing or selling and renting of property were appropriated by the social ethic from the personal, because leaving it to the personal was perceived as generating unfairness and injustice via discrimination. In general, the social ethic appropriates matters when leaving them to personal ethics is perceived as leading to morally unacceptable behavior. During the past 25 years, increasing amounts of animal treatment have been moved into the social ethic for these reasons; eg, laws regulating research, agriculture, animal shows, and so on.

Professional ethics stands midway between social and personal, and applies to subgroups of society engaged in important but highly specialized activities not well understood by society in general and requiring special expertise and special privileges. Thus veterinary or human medicine require specialized knowledge and enjoy special privileges-eg, dispensing pharmaceuticals, performing surgery. Society says, in essence, to professions: "you regulate yourselves the way we would regulate you if we understood what you were doing well enough to do so." Failure to meet this demand can result in illinformed people regulating the profession in question without understanding, as when perceived abuse of drugs in food animals by veterinarians led Congress to almost curtail extralabel drug use, which would have dealt a death blow to veterinary medicine.

Animal researchers are, of course, such a professional subgroup. When they failed to control pain and suffering or provide good animal care, US society moved in 1985 to regulate animal research despite protestations that such regulation would endanger human health. (In fact, it did no such thing, and almost certainly led to better research.) If they fail to consider-and implement-the social-ethical requirement of not creating animals who suffer greatly for long periods of time, society will almost certainly move to regulate such activities, even if researchers again protest that such regulation endangers human health.

The relevance of all this to toxicology should be clear. Even going back to the 1970s, toxicology on animals has been looked at with suspicion because of the suffering associated with LD 50 and Draize tests. The current international standards for toxicological evaluation of drugs in nonrodent species-dogs and monkeys-clearly can involve long-term suffering of up to a year. If this were widely known-attacked in the press - I believe this approach would quickly succumb to social concern about animal suffering. It will not do to cite "regulatory requirements" precisely because the social ethic trumps such requirements, and the bureaucrats who administer such regulations are typically clueless about social concerns. I would suggest that the field as currently constituted is living on borrowed time, and the appropriate response of you who practice toxicology is to work assiduously to meet social concerns.

How do you do this? In the first place, you must seek predictive criteria that involve less animal suffering, probably at the cellular and molecular levels. Secondly, pursue nonmammalian models more assiduously. Perhaps the "gold standard" of accepting lower animal models only if they replicate mammalian data is wrong, and they should be examined as possibly predictive on their own terms. Fifteen years ago, a colleague of mine developed planaria as toxicological models, and could not get funding or even a serious hearing because they were nonmammalian and excluded by fiat. More money should be put into 
in vitro modeling and such modalities as developing long-term anesthetized or decerebrate animals. Third, you should work to find and agree on much earlier endpoints in animal work, ideally those that predate suffering, yet are predictive of greater damage.

In the interim, all of these efforts should be publicized and promoted as desirable by the toxicological community. That community should never appear to be (or be) resistant to change that improves animal's welfare. Further, animal care and handling should be exemplary, and environments for housing should display state-of-the-art enrichment. Not only does this bespeak great concern for the animals you use, enriching environments is a known modality for controlling pain and suffering and, as in human medicine, is still the method of choice for dealing with chronic pain, ie, by deflecting attention. I believe that animals in general suffer more when we keep them in ways that violate their biological and psychological natures than from what we do to them.

By proactively embracing animal's welfare concerns, the toxicological community can turn vulnerability into strength by demonstrating moral concern and responsibility to the public. As the Stoic philosophers pointed out 2000 years ago, if one is chained to an oxcart, it is easier to walk when the cart does and rest with the oxen than to be dragged along broken and bleeding. Moral responsibility is a precondition of autonomy.

\section{References}

1. For a detailed account of the social conditions giving rise to the demand for a new ethic for animals, see B. Rollin: Farm Animal Welfare (Ames, lowa: lowa State University Press, 1995) Part I. For a philosophically based rational reconstruction of the new ethic see Rollin B (1992). Animal Rights and Human Morality, 2nd ed, Prometheus Buffalo, NY. For a utilitarian account of the newethic see Peter Singer: Animal Liberation (New York: New York Review of Books Press, 1975). For a rights based account see Tom Regan: The Case for Animal Rights (Berkeley: University of California Press, 1983).

2. de Greeve P, de LeeuwW(1997). Developments in Alternatives and Animal Use in Europe. In: Animal Alternatives, Welfare and Ethics, van Zutphen LFM, Balls M (eds). Elsevier, Amsterdam.

3. Shalev M (1998). European and U.S. regulation of monoclonal antibodies. Lab Animal, January, 1998. $15 \mathrm{ff}$.

4. O'donoghue P (1992). European regulation of animal experiments. Lab Animal, September 1991. 20 ff.

5. See Rollin BE (1989). The Unheeded Cry: Animal Consiousness, Animal Pain and Science, Oxford University Press, Oxford.

6. Gaskell G et al (1997). Europe ambivalent on biotechnology. Nature 387: $845 \mathrm{ff}$.

7. Rollin BE (1998). Social ethics, animal suffering, and the creation of transgenic animal models of human genetic disease. In: Bioethics and the Use of Laboratory Animals, Kraus AL, Renquist D (eds). American College of Laboratory Animal Medicine, Benoit, Dubuque, lowa, pp 109-123. 